\title{
FACTORS ASSOCIATED WITH VIOLENCE IN SCHOOLS: EXTENDING KNOWLEDGES AND PRACTICES FOR NURSING ${ }^{1}$
}

\author{
Camila Biazus Dalcin², Dirce Stein Backes ${ }^{3}$, Fabricio Batistin Zanatta ${ }^{4}$, Francisca Georgina Macedo de Sousa ${ }^{5}$, \\ Hedi Crecencia Heckler de Siqueira ${ }^{6}$, Adriane Maria Netto de Oliveira ${ }^{7}$
}

\footnotetext{
${ }^{1}$ Extracted from thesis - Factors associated with tobacco, illicit drugs and violence in schools of the public network: contributions for nursing, presented to the Programa de Pós-Graduação em Enfermagem, Universidade Federal do Rio Grande (FURG), in 2014.

${ }^{2}$ Master's student on the Programa de Pós-Graduação em Enfermagem, FURG. Rio Grande, Rio Grande do Sul, Brazil. E-mail: camilabiazus@hotmail.com

${ }^{3}$ Ph.D. in Nursing. Professor, Nursing Course, Centro Universitário Franciscano. Santa Maria, Rio Grande do Sul, Brazil. E-mail: backesdirce@ig.com.br

${ }^{4}$ Ph.D. in Dentistry. Professor, Undergraduate Course in Dentistry, Universidade Federal de Santa Maria. Santa Maria, Rio Grande do Sul, Brazil. E-mail: fabriciobzanatta@gmail.com

${ }^{5}$ Ph.D in Nursing. Professor, Nursing Course, Universidade Federal do Maranhão. São Luís, Maranhão, Brazil. E-mail: fgeorginasousa@ hotmail.com

${ }^{6}$ Ph.D. in Nursing. Professor, Nursing Course, FURG. Rio Grande, Rio Grande do Sul, Brazil. E-mail: hedihs@terra.com.br

7 Ph.D. in Nursing. Professor, Nursing Course, FURG. Rio Grande, Rio Grande do Sul, Brazil. E-mail: adrianenet@vetorial.net
}

\begin{abstract}
This study aimed to identify the factors associated with violence among students of public schools located in the central region of Rio Grande do Sul. It is an observational, transversal and analytical study. The sample was made up of 435 students aged from 10 to 19 years old. The data were collected through a structured questionnaire applied via interview. Associations between the dependent and independent variables were taken from the Poisson regression model. Once analyzed, the data evidenced greater prevalence between violence and the following variables: male sex, larger number of siblings, and a low income; while religion was associated as an indicator of protection for psychological violence. It is concluded that interdepartmental, interdisciplinary and multidimensional approaches constitute an important strategy for promoting health and reducing violence in schools, above all in communities with indicators of vulnerability. Specific strategies for the work of the nurse are indicated for preventing risks associated with violence.
\end{abstract}

DESCRIPTORS: Students. Violence. Adolescent health. Community health nursing. Nursing research.

\section{FATORES ASSOCIADOS À VIOLÊNCIA EM ESCOLARES: AMPLIANDO SABERES E PRÁTICAS PARA A ENFERMAGEM}

RESUMO: Objetivou-se identificar os fatores associados à violência em alunos de escolas públicas localizadas na região central do Rio Grande do Sul. Estudo observacional, transversal e analítico. Amostra foi constituída por 435 alunos de 10 a 19 anos. Os dados foram coletados por meio de questionário estruturado aplicado em forma de entrevista. Associações entre as variáveis dependentes e independentes foram retiradas do modelo de regressão de Poisson. Os dados analisados evidenciaram maior prevalência entre violência e as variáveis sexo masculino, maior número de irmãos e baixa renda, enquanto que a religião foi associada como indicador de proteção para a violência psicológica. Conclui-se que as abordagens intersetoriais, interdisciplinares e multidimensionais se constituem em importante estratégia para promoção da saúde e redução da violência escolar, sobretudo em comunidades com indicadores de vulnerabilidade. Estratégias específicas de atuação do enfermeiro são indicadas para prevenção de riscos associados a violência.

DESCRITORES: Estudantes. Violência. Saúde do adolescente. Enfermagem em saúde comunitária. Pesquisa em enfermagem. 


\section{FACTORES ASOCIADOS A LA VIOLENCIA EN ESCOLARES: AMPLIANDO CONOCIMIENTO Y PRÁCTICAS PARA LA ENFERMERÍA}

RESUMEN: El presente estudio tuvo como objetivo identificar factores asociados a violencia en estudiantes de escuelas públicas de la región central del Río Grande do Sul. Estudio observacional, analítico y transversal. La muestra estuvo conformada por 435 estudiantes de quinto grado de escuela primaria hasta el nivel secundario. Los datos fueron recolectados por medio de entrevistas utilizando cuestionario estructurado. Las asociaciones entre variables dependientes e independientes se tomaron del modelo de regresión de Poisson. El análisis de datos indicó un aumentó en la prevalencia entre violencia y variables de sexo masculino, mayor número de hermanos y bajos ingresos, mientras que la religión se asoció como indicador de protección de violencia psicológica. Se concluye que los enfoques intersectoriales, interdisciplinarios y multidimensionales se revelan como estrategias para acciones de enfrentamiento a la violencia. Algunas estrategias específicas de intervenciones de enfermería son indicadas para prevenir los riesgos asociados a violencia.

DESCRIPTORES: Estudiantes. Violencia. Salud del adolescente. Enfermería en salud comunitaria. Investigación en enfermería.

\section{INTRODUCTION}

Violence is revealed to be an important component in discussions on health due to its impact on individual and collective health. It is a growing social problem, revealed through the rates of morbidity and mortality of victims of violence. ${ }^{1}$ In this perspective, violence goes beyond aggression per se, due to the consequences reflected in society, often causing fear and restrictions for the people involved in it and weaving various interrelationships which affect the whole and the parts which integrate the context characterized by violence. ${ }^{2}$

In research, children and adolescents emerge as the main victims of violence, considering that this practice constitutes one of the main causes of death in these age groups..$^{2-3}$ When the violence takes place in schools, it can come to prejudice their potential for being shaped as a person and citizen, which can lead to a poor quality of social life, besides causing individual and collective suffering. ${ }^{2}$ Adolescents' exposure to a wide variety of forms of violence can lead to the development of illnesses such as depression, and other risks to their health. ${ }^{4}$

One study ${ }^{5}$ evidences the prevalence of violence at $18.9 \%$ in the age range from 12 to 19 years old among students at basic education ${ }^{*}$ and senior high school level in public schools. The predominance was for individuals of the male sex, who used alcohol and other drugs, and whose family relationships were not satisfactory. ${ }^{6}$ Another study undertaken with 399 adolescents in an outpatient center in Pernambuco showed a rate of $41.4 \%$ of violence, within which the most frequent types were psychological and moral bullying (66.7\%); within this context, $33 \%$ of the adolescents reported that the aggression was recurrent. ${ }^{7}$ The violence appears on a large scale in the school space, showing the need for broad and interdisciplinary approaches so as to address the multiple causes. This environment, which should be one of protection and strengthening of the student, can end up turning into a space of violence itself, harming physical, psychological and moral aspects. ${ }^{6,8}$

Violence, as a social event, has been revealed to be associated with various factors, ${ }^{5,7-9}$ such as: fragility of intrafamilial relationships, absence of warmth and of limits, complicated relationships with fathers or mothers, unpreparedness on the part of the school, poor educational performance, absence of things to do, drug use, conflicts in the community, use of weapons, social inequalities, and poverty, among others.

Based on these assertions, it becomes compelling to hold broad and complex discussions on the issue of violence, in particular, in regions with indicators of vulnerability, due to there existing a significant association between a worse state of health and greater indicators of violence in more vulnerable communities. ${ }^{10-11}$ Vulnerable communities are understood as those which experience environmental, economic, political and cultural influences which weaken the individual, familial and social relationships and associations. ${ }^{12}$ The study of the indicators of violence and of the context of the student who lives in vulnerable communities is revealed to be a possibility for extending strategic actions for healthcare. ${ }^{13}$

In order to stimulate a new understanding of health in the light of these problems, which by their nature are complex, one requires a new way of thinking and acting - also complex. It is necessary to describe the complexity of the phenomena which emerge from the violence, for these to be analyzed under a new perspective, a perspective which weaves together the interactions, thus leading to a broadened and contextualized view of the emerging social realities. ${ }^{14}$

To this end, one requires qualified professionals, including the nurse, who are capable of inter-

* Primary and junior high school. Translator's note. 
vening in an articulated and proactive way in the different social contexts. ${ }^{15}$ Considering the importance of identifying the factors related with violence in schools, as well as how to intervene proactively and responsibly, above all in regions with indicators of vulnerability, the question is raised: What factors are associated with violence in schools? With the objective of answering this question, the present study aimed to identify the factors associated with violence among students of public schools located in the Central Region of Rio Grande do Sul.

\section{METHOD}

This is an observational, transversal and analytical study. Its unit of analysis is the individual. It is part of the "Promotion and education for the health of children and adolescents of public schools of a vulnerable communities" project, financed by the Research Support Foundation of the State of Rio Grande do Sul (FAPERGS), approved by the FAPERGS 02/2011 - PqG bid for tender.

The study was undertaken with students aged from 10 to 19 years old who lived in a community with approximately 26,000 inhabitants, in the West Region of the municipality of Santa Maria Rio Grande do Sul (RS), Brazil. The community in question has indicators of social vulnerability, suffering unfavorable rates for its growth and strengthening such as, for example, social inequalities and difficulties in accessing the various services provided by the state.

The sample size was previously calculated through sample calculation in six state schools of small, medium and large size, located in the abovementioned community. This calculation was made based on the following formula: $n$ school $=(n$ total calculated X $n$ total in the school) / 3,659 (total number in all the schools). In order to obtain the number of interviewees, the same proportional system was undertaken, considering the total number of students in each school and the total number in each classroom.

From a total of 3,659, a sample was calculated of 435 students for this study, based on an outcome of $50 \%$, with a confidence interval of $95 \%$ and a non-response rate of $30 \%$. The eligibility criteria included the students enrolled in the state schools selected for the study, who were residents of the above-mentioned community, and who were aged between 10 and 19 years old at the time of the research. The signing of the Terms of Free and Informed Consent, on the part of those responsible for the students, was the indispensable criteria for participating in the study. The research project was approved by the Research Ethics Committee of the Centro Universitário Franciscano (UNIFRA), under N. 285/2011.

The data were collected through a structured questionnaire, applied via interview, with the help of researchers from the health area, this data collection instrument being based on a questionnaire validated for research in a previous study on the issue of a violence among adolescents. ${ }^{16}$ Firstly, a pilot study was undertaken with 15 students from the above-mentioned schools. Based on the analysis of these initial data, some questions were changed for better adaptation of the questionnaire, due to the region's specific needs. The data were collected between October 2011 and December 2012, in six state schools of small, medium and large size, located in the above-mentioned community.

The data were presented through distribution of simple and relative frequency. Associations between the dependent and independent variables were firstly calculated using the Poisson regression model, as well as the prevalence ratios (PR) and the confidence interval of (CI) $95 \%$ being presented. The outcome variables considered were: "Have you ever suffered some type of violence?" (yes; no), "If you have suffered violence, what type was it?" (physical/sexual: psychological). The independent variables were: sex (female; male), age dichotomized by the median ( $\leq 4$ years old; $>14$ years old), race (Caucasian; others), housing situation (living with parents; living with others), number of siblings $(\leq 2 ;>2)$, family income dichotomized by minimum Brazilian monthly salary at the time of data collection ( $\leq$ US\$ 232.00; >US\$ 232.00), educational level dichotomized by median ( $\leq 8$ years; $>8$ years), time at which the student studies (daytime; night-time), whether the student has been held back a year in school (yes; no), occupation (only studies; studies and works; and religion (has a religion; does not have a religion).

The statistical level was 5\% $(p=0.05)$ and the software used was the Statistical Package for the Social Sciences (SPSS), version 18.0 for Windows. A multivariate analysis was run using the Poisson regression model, considering the following outcomes: suffering violence, and type of violence suffered. Adjusted and non-adjusted Poisson regression models with robust variance were calculated in order to ascertain the ratios of prevalence of the dependent and independent variables. An adjustment was undertaken for all the variables with a p-value $<0.2$ in the univariate analysis. In order to select the variables which were retained in the multivariate 
model, a stepwise backward procedure was adopted, eliminating, one by one, the variables with higher $p$ values - until only variables with $\mathrm{p}<0.05$ remained. For the outcome of 'type of violence', the variables of "sex" and "number of siblings" were kept in the final model, independently of the p-value.

\section{RESULTS}

The total sample was of 435 students, with a non-response rate below $10 \%$. The predominant characteristics in the students interviewed were: female sex, family income higher than US\$232.00, fewer than eight years of study, age equal to or less than 14 years old, and Caucasian. Among the adolescents studied, $18.9 \%$ reported having suffered some type of violence. For those who responded that they had suffered violence, 59.8\% responded that they had suffered physical/sexual violence, and $40.2 \%$ had suffered psychological violence. The demographic characteristics, and characteristics related to school behavior are described in Table 1.

Table 1 - Characteristics of the population studied. Santa Maria-RS, 2014

\begin{tabular}{|c|c|c|}
\hline Characteristics & $\mathbf{n}$ & $(\%)$ \\
\hline \multicolumn{3}{|l|}{ Sex } \\
\hline Female & 244 & $56.1 \%$ \\
\hline Male & 191 & $43.9 \%$ \\
\hline \multicolumn{3}{|l|}{ Age } \\
\hline$\leq 14$ years old & 220 & $50.6 \%$ \\
\hline$>14$ years old & 215 & $49.4 \%$ \\
\hline \multicolumn{3}{|l|}{ Race } \\
\hline Caucasian & 276 & $63.4 \%$ \\
\hline Others & 159 & $36.6 \%$ \\
\hline \multicolumn{3}{|l|}{ Housing situation } \\
\hline With parents & 370 & $85 \%$ \\
\hline With others & 65 & $15 \%$ \\
\hline \multicolumn{3}{|l|}{ Number of siblings } \\
\hline$\leq 2$ & 236 & $54.2 \%$ \\
\hline$>2$ & 199 & $45.8 \%$ \\
\hline \multicolumn{3}{|l|}{ Religion } \\
\hline Has a religion & 335 & $77 \%$ \\
\hline Does not have a religion & 100 & $23 \%$ \\
\hline \multicolumn{3}{|l|}{ Monthly family income } \\
\hline > U\$232.00 & 340 & $78.2 \%$ \\
\hline$\leq \mathrm{U \$} 232.00$ & 95 & $21.8 \%$ \\
\hline \multicolumn{3}{|l|}{ Occupation } \\
\hline Studies & 359 & $82.5 \%$ \\
\hline Studies and works & 76 & $17.5 \%$ \\
\hline \multicolumn{3}{|l|}{ Educational level } \\
\hline$\leq 8$ years & 229 & $52.6 \%$ \\
\hline$>8$ years & 206 & $47.4 \%$ \\
\hline \multicolumn{3}{|l|}{ Time when studies } \\
\hline Daytime & 340 & $78.2 \%$ \\
\hline Night-time & 95 & $21.8 \%$ \\
\hline \multicolumn{3}{|l|}{ Has been held back a year in school } \\
\hline No & 233 & $53.6 \%$ \\
\hline Yes & 202 & $46.4 \%$ \\
\hline \multicolumn{3}{|l|}{ Has suffered violence } \\
\hline No & 353 & $81.1 \%$ \\
\hline Yes & 82 & $18.9 \%$ \\
\hline \multicolumn{3}{|l|}{ Type of violence } \\
\hline Physical/Sexual & 49 & $59.8 \%$ \\
\hline Psychological & 33 & $40.2 \%$ \\
\hline Total & 435 & $100 \%$ \\
\hline
\end{tabular}


Table 2 analyzes the indicators of demographic and school-related prevalence related to the outcome "Have you suffered any type of violence?". In the univariate analysis, male sex increased the probability of suffering violence by 1.48 times. Regarding the independent variable of "housing situation", the data collected showed that living with people who were not one's parents led to a prevalence 1.65 times greater of suffering violence. In relation to the statistical association between number of siblings and the outcome of suffering violence, it was possible to perceive that having a number of siblings greater than two increased by $114 \%$ the prevalence of the students suffering violence $(p=0.00)$.

Table 2 - Indicators of demographic and school-related prevalence associated with the outcome of suffering violence, Santa Maria-RS, 2014. $(n=82)$

\begin{tabular}{|c|c|c|c|c|c|c|c|}
\hline & \multicolumn{7}{|c|}{ Violence } \\
\hline & $\mathbf{n}$ & $\%$ & $\%$ total & PR (CI95\%) & p & PR (CI 95\%)* & $\mathrm{p}$ \\
\hline \multicolumn{8}{|l|}{ Sex } \\
\hline Female & 38 & 46.3 & 8.73 & 1 & \multirow[t]{2}{*}{0.04} & 1 & \multirow[t]{2}{*}{0.03} \\
\hline Male & 44 & 53.7 & 10.11 & $1.48(1.01-2.16)$ & & $1.47(1.02-2.12)$ & \\
\hline \multicolumn{8}{|l|}{ Age } \\
\hline$\leq 14$ years old & 47 & 57.3 & 10.80 & 1 & \multirow[t]{2}{*}{0.36} & & \\
\hline$>14$ years old & 35 & 42.7 & 8.04 & $0.83(0.56-1.22)$ & & $\dagger$ & \\
\hline \multicolumn{8}{|l|}{ Race } \\
\hline Caucasian & 49 & 59.8 & 11.26 & 1 & \multirow[t]{2}{*}{0.37} & & \\
\hline Others & 33 & 40.2 & 7.58 & $1.19(0.80-1.75)$ & & $\dagger$ & \\
\hline \multicolumn{8}{|l|}{ Housing situation } \\
\hline With parents & 63 & 76.8 & 14.48 & 1 & \multirow{2}{*}{0.02} & & \\
\hline With others & 19 & 23.2 & 4.36 & $1.65(1.07-2.53)$ & & $\ddagger$ & \\
\hline \multicolumn{8}{|l|}{ Number of siblings } \\
\hline$\leq 2$ & 33 & 40.2 & 7.58 & 1 & \multirow[t]{2}{*}{0.00} & 1 & \multirow[t]{2}{*}{0.00} \\
\hline$>2$ & 49 & 59.8 & 11.26 & $2.14(1.45-3.16)$ & & $2.03(1.39-2.80)$ & \\
\hline \multicolumn{8}{|l|}{ Religion } \\
\hline Has religion & 56 & 68.3 & 12.87 & 1 & \multirow[t]{2}{*}{0.02} & & \\
\hline Does not have religion & 26 & 31.7 & 5.97 & $1.58(1.06-2.36)$ & & $\ddagger$ & \\
\hline \multicolumn{8}{|l|}{ Monthly family income } \\
\hline > U\$232.00 & 49 & 59.7 & 11.26 & 1 & \multirow[t]{2}{*}{0.00} & 1 & \multirow[t]{2}{*}{0.00} \\
\hline$\leq \mathrm{U} \$ 232.00$ & 33 & 40.3 & 7.58 & $2.11(1.46-3.07)$ & & $1.98(1.38-2.83)$ & \\
\hline \multicolumn{8}{|l|}{ Occupation } \\
\hline Studies & 61 & 74.4 & 14.02 & 1 & \multirow[t]{2}{*}{0.06} & & \\
\hline Works and studies & 21 & 25.6 & 4.82 & $1.50(0.97-2.30)$ & & $\ddagger$ & \\
\hline \multicolumn{8}{|l|}{ Educational level } \\
\hline$\leq 8$ years of study & 49 & 59.8 & 11.26 & 1 & \multirow[t]{2}{*}{0.38} & & \\
\hline$>8$ years of study & 33 & 40.2 & 7.58 & $0.84(0.57-1.24)$ & & $\dagger$ & \\
\hline \multicolumn{8}{|l|}{ Time at which studies } \\
\hline Daytime & 61 & 74.4 & 14.02 & 1 & \multirow{2}{*}{0.07} & & \\
\hline Night-time & 21 & 25.6 & 4.82 & $1.46(0.95-2.22)$ & & $\ddagger$ & \\
\hline \multicolumn{8}{|c|}{ Has been held back a year at school } \\
\hline No & 36 & 43.9 & 8.27 & 1 & \multirow[t]{2}{*}{0.08} & & \\
\hline Yes & 46 & 56.1 & 10.57 & $1.40(0.95-2.07)$ & & $\ddagger$ & \\
\hline
\end{tabular}

*Prevalence ratio adjusted for sex, number of siblings and monthly family income; $†$ Variables which did not enter the adjusted analysis; $\ddagger$ Variables which were not retained in the final model.

In relation to religion, it was evidenced that not having a religion is an indicator, increasing the prevalence of suffering violence by 1.58 times. The independent variable of monthly family income showed a statistical association $(p=0.00)$ with the outcome studied, and a monthly family income of less than or equal to US $\$ 232.00$ showed a prevalence which was 2.11 times higher of suffering violence. After adjustment of the following variables: sex, housing situation, number of siblings, religion, monthly family income, occupation, time at which studies and having been held back a year in school for the multivariate 
model, housing situation and religion were retained in the final adjusted model. The statistical association with the outcome of "suffering violence" and the variables of sex (PR 1.47; CI 95\% 1.02-2.12), "number of siblings" (PR 2.03; CI 95\% 1.39-2.90) and "monthly family income" (PR 1.98; CI 95\% 1.38-2.83) remained.

Table 3 - Indicators of demographic and school-related prevalence associated with the outcome of "type of violence". Santa Maria-RS, 2014. $(n=82)$

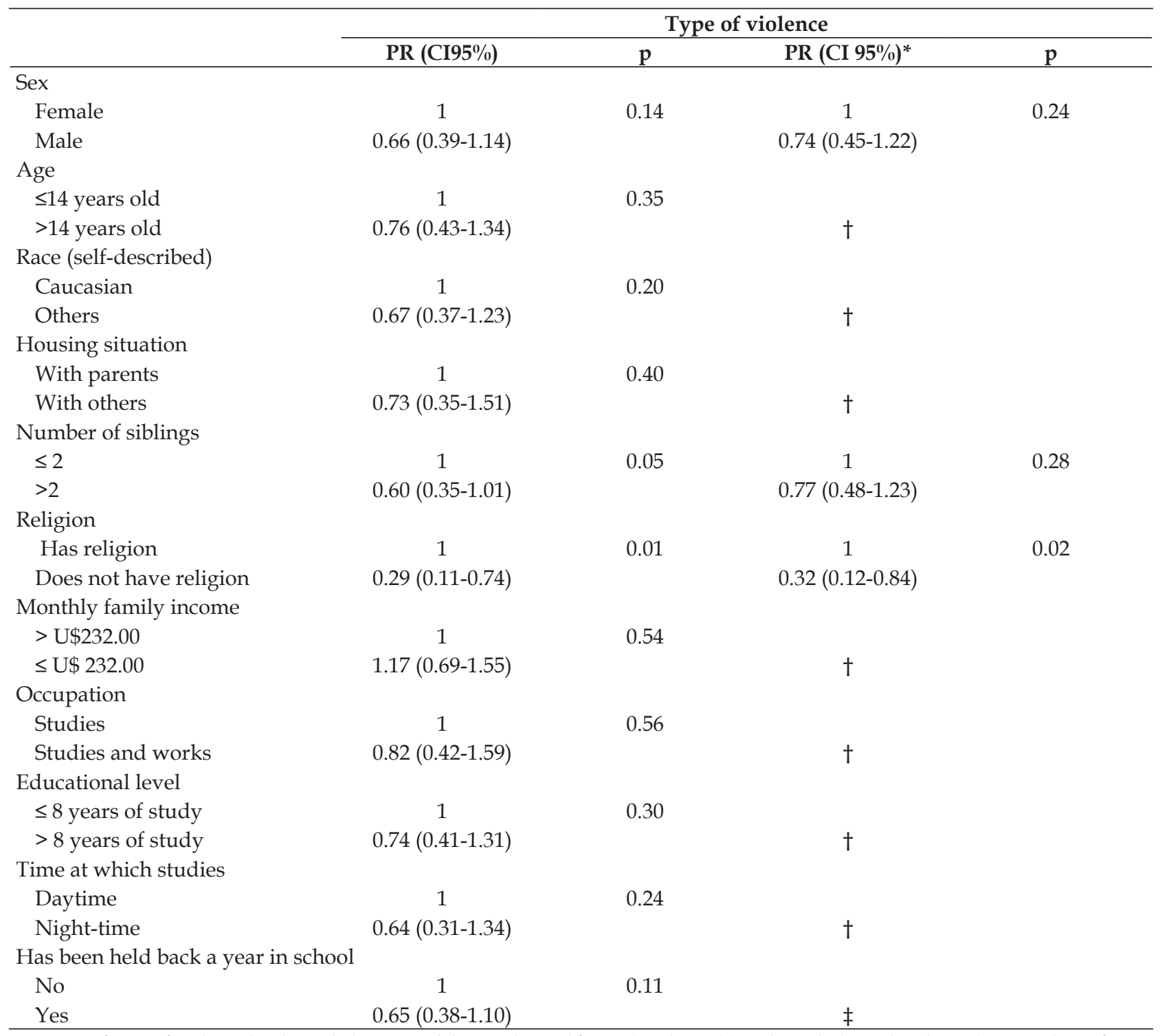

Outcome of type of violence has been dichotomized, being physical/sexual violence (0) and psychological violence (1 - prevalence factor), in the raw model and in the adjusted model; *Prevalence ratio adjusted for number of siblings and religion; $†$ Variables which did not enter the adjusted analysis; $\ddagger$ Variables which were retained in the final model.

The data related to the risk indicators of the outcome of type of violence suffered were described in Table 3. For the variable of "number of siblings", the students who had a number higher than two presented a probability $60 \%$ higher of suffering psychological violence than of suffering physical/ sexual violence. In relation to religion, having a religion reduced the prevalence of suffering psychological violence by $71 \%$. For the multivariate model, the variables of sex, number of siblings, religion and being held back one year in school were adjusted. After the adjustment, the variable of "number of siblings" lost its statistical significance for the outcome of "type of violence", with only religion remaining as a prevalent indicator of protection against psychological violence (PR 0.32; CI95\% 0.12-0.82) associated with the outcome of "type of violence". 


\section{DISCUSSION}

Violence is, per se, a complex phenomenon, on the rise in the most differing of social contexts, as has been evidenced in various studies. One study undertaken with 699 students from the region of Barra do Garças, in the Brazilian State of Mato Grosso revealed that the prevalence of the behavior of violence among adolescents was $18.6 \%{ }^{6}$, corroborating the present study, which showed a frequency of violence suffered of $18.9 \%$. One study with 229 adolescents in outpatient services of a tertiary public pediatric hospital ascertained that only five adolescents reported not suffering psychological violence, showing the extent to which this issue is present in adolescents' lives and that, often, it is confounded with normality. ${ }^{17}$

An adolescent is considered to be an individual in transition, due to the biological development and transformations which are inherent to the age. ${ }^{18}$ In this stage of life, the individual is more vulnerable to the processes of complex social interactions, such as, for example, violence, in which he or she seeks reaffirmation of his or her values and beliefs. The social spaces in which the student is inserted, therefore, must be receptive to understanding her context and must offer support for promoting humane integration and strengthening of the interrelationships. The school, therefore, can be a healthy social space strategy for adolescents.

Being of male sex appears in research as a risk indicator for the phenomenon of violence. ${ }^{6}$ The association with violent behavior is related to prevalent factors such as alcohol use, drug use, being of the male sex, and having a relationship with parents which is not satisfactory. ${ }^{6,19}$ Living with parents, as protection for not suffering violence, may have lost statistical significance in the multivariate analysis, due to the family being understood as a system in which violence occurs, and not as a protective factor for the adolescents. ${ }^{20}$ However, when the family interacts satisfactorily, it contributes to the consolidation of atmospheres which are healthy for human and social development. As a result, it is fundamental for investment to be made in promoting family health, as a complex unit in the network of relationships and social associations.

In this study, it was evidenced that the economic situation of the student is associated with the complex phenomenon of violence. Unfavorable living conditions, and few opportunities, due to low purchasing power, may be factors for a greater tendency to become involved in situations of violence. ${ }^{20}$ This evidence is contrary to that of a separate study undertaken, ${ }^{6}$ which indicated that adolescents from families with better socioeconomic situations present a greater probability of behaviors of violence. Within this perspective, it is revealed to be necessary to highlight that the interaction of the social determinants of health influences situations of violence of adolescents; including social, economic, cultural, and behavioral factors, among others. ${ }^{21}$

Religion, related to a set of rituals and beliefs, appears as an indicator of protection for not suffering psychological violence, coming to contradict that found in a previously undertaken study, which did not show religion as associated with the variables of violence. ${ }^{22}$ It is believed that this factor of protection against psychological violence emerges through the influence of religious thinking in the individuals' behaviors, taking into account that religions are associated with spaces for meeting - and that, consequently, they constitute social spaces. One study undertaken $^{23}$ showed the importance of religious groups for reducing violence among adolescents, bearing in mind that these are characterized as spaces for affective exchange and which have a disciplinary effect on human behavior.

Dysfunctional families, who experience a high frequency of disturbed family relationships, are associated with different forms of violence. ${ }^{17}$ The increase in the number of siblings indicates a greater tendency for the phenomenon of violence. Therefore, in this process, emphasis is placed on Brazil's National Health Promotion Policy, which aims to cover each part in its whole, as well as the whole - the family - in the interrelationship with each part - the individual. It is important that in this interdependence, there should be effective and affective dialogical exchanges for the encouragement of healthy behaviors. Through this Brazilian health policy, it is aimed to reduce vulnerabilities and improve quality of life, strengthening family relationships in a positive way. ${ }^{24}$

It was observed in this study, as also in other studies, that relationships in the family environment which are not satisfactory and are divisive generate violent behaviors. ${ }^{6,17,25}$ Intrafamily violence was mentioned by $9.5 \%$ of one sample of a conglomerate of 60,973 students from basic education in state and private schools of the capitals of the Brazilian states and of the Federal District. ${ }^{5}$

Dissatisfactory family relationships can emerge from a family dynamic which requires (re-) organization. Visualizing the individuals and their family system is revealed to be a relevant strategy for better coexistence between the family members, causing the family interactions to have the impor- 
tance of the whole which they are made up from. Public policies and actions in the schools, encouraging cooperative work between students and their family members, constitute strategies which are increasingly urgently needed for strengthening the relationships and healthy social interactions.

The area of health has a privileged space in the family group and, due to this, must act in preventing violence and in practices of health promotion. ${ }^{26}$ The nurse must be aware of her personal and professional commitment to the human being, in order to understand the student, the families and the living contexts, thus being able to perceive the interactions established between children and adolescents, acting as a mediator in a process of organization of a new family order, through bond and dialogue.

Investigations have identified correlations between the different forms of violence suffered by the adolescents. ${ }^{17,26-27}$ There was no difference in the frequency of the $59.8 \%$ who suffered physi$\mathrm{cal} / \mathrm{sexual}$ violence and of the $40.2 \%$ who suffered psychological violence. It is therefore necessary for the nurse, as a professional who articulates knowledges, through a broad view, to be able to perceive the students in their context and not to separate them from it. Only in the interaction with the family, school and community would it be possible to perceive the complexity of the issue of violence and which strategies may be outlined through dialogue with a single context in its multiple interactions.

Through complex thought, the Dialogic Principle goes far beyond synthesis, integrating and understanding ideas considered to be antagonistic in sets. ${ }^{28}$ A dialogicity between student, family, school and context is configured as a strategy such that one may eliminate the existence of a single truth through the understanding of the local context and of the autonomy of each component of the system.

Violence is, therefore, a complex phenomenon which cannot be disassociated from its family and community context. The factors associated with violence show the need for an interdepartmental, transdisciplinary and multidimensional approach, articulating service networks for the elaboration of public policies for effective confrontation of the same. ${ }^{8}$ This being the case, interdepartmental approaches constitute an important strategy for promoting health and reducing school violence, above all in communities with indicators of vulnerability, so as to transcend the linearity of piecemeal and verticalized actions. ${ }^{14}$

Interdepartmental policies show the necessity for professional training and preparation for identifying, notifying and monitoring students in situations of violence, the support of the authorities being necessary if there is to be resolution of issues related to this question which is both social and related to public health. ${ }^{17}$ With healthcare as the objective, professional nurses can integrate knowledges through transdisciplinary knowledge of the contexts proposed ${ }_{1}^{29}$ with an increasingly recognized social aspect to their work, capable of being articulators in the different social fields. ${ }^{30}$

Transdisciplinary knowledge is associated, in its turn, with the dynamic of the multiplicity of the dimensions of reality and of human beings, in which the fragmentation of knowledge does not hinder the social needs. It is necessary for there to be interconnection of knowledges through the articulation of antagonistic concepts, leading to a logical contradiction of health with situations of vulnerability, interlinked by the networks of associated factors such as family income, sex, number of siblings and specific cultural processes. Transdisciplinarity, as a possibility for the construction of knowledge in integrated and continuous movement, requires the comprehension of the human condition, through a crossing of disciplines, constructing a relevant knowledge together. ${ }^{14}$

In order for the multidimensionality of the students to be perceived, broadened and contextualized approaches by the nurse are required, such as, for example, the perspective of complexity. The individual needs to be perceived in her multiple dimensions, this being, at the same time, biological, psychic, social and spiritual. ${ }^{14}$ In the academic training, the nurse must be inserted and prepared to perceive the multiple dimensions which surround questions of students' health, not reducing the social conditions to the individual, and the individual to the social conditions. Through the understanding and the bond with the community, the nurse will be able to act in the issue of violence and in its repercussions in communities with indicators of vulnerability. Future studies must address specific strategies for the work of the nurse in the different contexts, with regard to mediating processes of reorganization related to the intervenient aspects of violence in the life of students, families and communities.

\section{FINAL CONSIDERATIONS}

The results evidenced that the factors associated with exposure to violence in students of the public educational network of a community with indicators of vulnerability in the South of Brazil are sex, number of siblings and family income, and that the type of violence suffered is related, in particular, to religion.

Violence is, per se, a complex phenomenon. Working on the multiple factors which surround 
this complexity, therefore, will enable as a broad understanding of this social and health issue. The interactions between the student, families and communities must be strengthened, so as to perceive violence in the economic, social, environmental and cultural contexts. Studies which address specific strategies for the work of the nurse must be undertaken for the prevention of risks associated with violence in vulnerable communities.

In summary, it is concluded that interdepartmental, interdisciplinary and multidimensional approaches constitute important strategies for the promotion of health and the reduction of school violence, above all in communities with indicators of vulnerability. As alternatives for change, the effective implementation is suggested of the Health Promotion Policy in communities with indicators of vulnerability; the active insertion of the professional nurse into the school space, and the institutionalization of healthy practices, both in the school space and in the family and community.

The study's limitations are those relating to the method chosen, as the reverse causality bias cannot be eliminated in transversal research.

\section{ACKNOWLEDGMENTS}

The authors express their gratitude to the Research Support Foundation of the State of Rio Grande do Sul (FAPERGS), through the Gaúcho Researcher Program (PqG) (Programa Pesquisador Gaúcho) Bid for Tender, to the Coordination for the Improvement of Higher Education Personnel (CAPES) (Master's program grant), and for the contributions of other colleagues and students who contributed directly or indirectly to the undertaking of this study.

\section{REFERENCES}

1. Ribeiro AP. Jovens em risco social: avaliação de programas de prevenção à violência armada [resenha]. Cad Saúde Pública [Internet]. 2015 [cited 2016 Mar 01]; 31(2):437-9. Available from: https:// dx.doi.org/10.1590/0102-311XRE020215

2. Andrade SSCA, Yokota RTC, Sá NNB, Silva MMA, Araújo WN, Mascarenhas MDM, et al. Relação entre violência física, consumo de álcool e outras drogas e bullying entre adolescentes escolares brasileiros. Cad Saúde Pública [Internet]. 2012 [cited 2015 Jul 01]; 28(9):1725-36. Available from: http:/ / www.scielo.br/scielo.php? script $=$ sci $_{-}$ arttext\&pid=S0102311X2012000900011\&lng=pt

3. Santos TMB, Sousa TDA, Rocha GSA, Silva LMP. Analysis of the scientific production on the notification of violence against adolescents. Rev Bras Prom Saúde [Internet]. 2014 [cited 2016 Fev 28]; 27(4):560-
7. Available from: http://ojs.unifor.br/index.php/ RBPS/article/view/2750/pdf_1

4. Dunn EC, Gilman SE, Willett JB, Slopen NB, Molnar $\mathrm{BE}$. The impact of exposure to interpersonal violence on gender differences in adolescent-onset major depression: results from the national comorbidity survey replication. Depress Anxiety. 2012 May; 29(5):392-9.

5. Malta DC, Souza ER, Silva MMA, Silva CS, Andreazzi MAR, Crespo C, et al. Violence exposures by school children in Brazil: results from the National Adolescent School-based Health Survey (PeNSE). Ciênc Saúde Coletiva [Internet]. 2010 [cited 2015 Jul 7]; 15(Supl.2):3053-63. Available from: http:/ / www. scielo.br/pdf/csc/v15s2/a10v15s2

6. Castro ML, Cunha SS, Souza DPO. Violence behavior and factors associated among students of central-west Brazil. Rev Saúde Pública [Internet]. 2011 [cited 2014 Set 11]; 45(6):1054-61. Available from: http://www. scielo.br/scielo.php?script=sci_arttext\&pid=S0034$89102011005000072 \& \operatorname{lng}=$ en\&nrm=iso\&tlng $=$ en

7. Oliveira MTD, Lima MLCD, Barros MDDA, Paz AM, Barbosa AMF, Leite RMB. Under-reporting of domestic violence among adolescents: the (in)visibility of the demand for outpatients care at a health service in the city of Recife, Brazil. Rev Bras Saúde Matern Infant [Internet]. 2011 [cited 2014 Jul3]; 11(1):29-39. Available from: http:/ / www.scielo.br/scielo.php?pid=S151938292011000100004\&script=sci_abstract

8. Finkelhor D, Turner H, Shattuck A, Hamby S, KrackeK. Children's exposure to violence, crime, and abuse: an update. National survey of children's exposure to violence [Internet]. USA. 2015 Set [cited 2016 Mar 2]. Available from: http://www.ojjdp.gov/pubs/248547.pdf

9. Cruz GP, Rocha MF, Wolffenbüttel CR. Indisciplina e violência escolar: uma análise sobre o papel da escola frente às ações de prevenção. In: Anais do $8^{\circ}$ Encontro de Pesquisa em Arte da FUNDARTE e $3^{\circ}$ Seminário dos Grupos de Pesquisa da UERGS/Montenegro [Internet]. 2015 [cited 2016 Mar 4]; (8):258. Available from: http://seer. fundarte.rs.gov.br/index.php/epa/article/view/289

10. Barata RB, Ribeiro MCSA, Cassanti AC. Social vulnerability and health status: a household survey in the central area of a Brazilian metropolis. Cad Saúde Pública [Internet]. 2011 [cited 2014 Dez 3]; 27(2). Available from: http://www.scielo.br/scielo.php?pid=S0102-311X2011001400005\&script=sci_arttext

11. Denis JL. Institucionalização da avaliação na administração pública. Rev Bras Saúde Matern Infant [Internet]. 2010 [cited 2014 Dez 2]; 10(Supl.1):s229-333. Available from: http://www.scielo.br/scielo.php?pi $\mathrm{d}=$ S1519-38292010000500020\&script=sci_arttext

12. Grupo de Estudos e Pesquisa em Empreendedorismo Social da Enfermagem e Saúde. Validação de conceito de comunidade vulnerável na perspectiva da complexidade. Conceito discutido e validado no grupo de pesquisa. Santa Maria (RS): GEPESES; 2011.

13. Backes DS, Backes MS, Erdmann AL, Büscher A, Maya MAS. Significado da prática social do enfermeiro com e a partir do Sistema Único de Saúde brasileiro. Aquichán [Internet]. 2014 Dec 
[cited 2016 Mar 10]; 14(4):560-70. Available from: http:/ / www.scielo.org.co/scielo.php?script=sci_ arttext\&pid=S1657-59972014000400010\&lng=en. http://dx.doi.org/10.5294/aqui.2014.14.4.10.

14. Santos SSC, Hammerschmidt KSA. A complexidade e a religação de saberes interdisciplinares: contribuição do pensamento de Edgar Morin. Rev Bras Enferm, [Internet]. 2012 [cited 2014 Feb 02]; 65(4):561-5. Available from: http://www.scielo.br/pdf/reben/ v65n4/a02v65n4.pdf

15. Aragão AS, Ferriani MGC, Vendruscollo TS, Souza SL, Gomes R. Abordagem dos casos de violência à criança pela enfermagem, na atenção básica. Rev Latino-Am Enfermagem [Internet]. 2013 [cited 2014 Nov 3]; 21(Spec). Available from: http:/ / www.scielo. $\mathrm{br} / \mathrm{pdf} /$ rlae/v21nspe/pt_22.pdf

16. Barros ACMW, Bastos O, Pone MVS, Deslandes $\mathrm{SF}$. Domestic violence and the adolescent that was infected with HIV through vertical transmission: analysis of protection and vulnerability factors. Ciênc Saúde Coletiva [Internet]. 2013[cited 2014 Jul 2]; 18(5):1493-500. Available from: http:// www.scielo.br/scielo.php?script=sci arttext\&pid=S1413-81232013000500035

17. Abranches CD, Assis SG, Pires TO. Violência psicológica e contexto familiar de adolescentes usuários de serviços ambulatoriais em um hospital pediátrico público terciário. Ciênc Saúde Coletiva [Internet]. 2013[cited 2014 Out 7]; 18(10):2995-3006. Available from: http:// www.scielo.br/scielo.php?pid=S1413$81232013001000024 \&$ script $=$ sci_arttext

18. Ferronato VFO. A importância da família na formação social do adolescente. Rev Educ [Internet]. 2015 [cited 2016 Mar 2]; 18(24):3-9. Available from: http:/ / www. pgsskroton.com.br/seer/index.php/educ/article/ view/3341/3008

19. Moreira DP, Vieira LJES, Pordeus AMJ, Lira SVG, Luna GLM, Silva JG. Machado MFAS. Exposure to violence among adolescents in a low-income community in the northeast of Brazil. Ciênc Saúde Coletiva [Internet]. 2013 [cited 2014 Ago 22];18(5):1273-82. Available from: http://www.scielo.br/scielo.php?script=sci arttext\&pid=S1413-81232013000500012

20. Hildebrand NA, Celeri EHRV, Morcillo AM, Zanolli MDL. Violência doméstica e risco para problemas de saúde mental em crianças e adolescentes. Psicol: Reflex Crít [Internet]. 2015 [cited 2016 Mar 2]; 28(2):213-21. Available from: http://www.scielo.br/pdf/prc/ v28n2/0102-7972-prc-28-02-00213.pdf

21. Palipudi KM, Gupta PC, Sinha DN, Andes LJ, Asma $\mathrm{S}$, McAfee T, et al. Social determinants of health and tobacco use in thirteen low and middle income countries: evidence from global adult tobacco survey. PLoS ONE [Internet]. 2012 [cited 2015 Jun 23]; 7(3):e33466. Available from: http://journals.plos.org/ plosone $/$ article?id=10.1371/journal.pone. 0033466

22. Mello-Silva ACC, Brasil VV, Minamisava R, Oliveira LMAC, Cordeiro JABL, Barbosa, MA. Quality of life and psychological trauma in firearm violence victims. Texto Contexto Enferm [Internet]. 2012 [cited 2014 Ago 22]; 21(3):558-65. Available from: http://www. scielo.br/pdf/tce/v21n3/v21n3a10.pdf

23. Salas-Wright CP, Vaughn MG, Hodge DR, Perron BE. Religiosity profiles of american youth in relation to substance use, violence, and delinquency. J Youth Adolescence. 2012 Dez; 41(22):1560-75.

24. Malta DC, Silva MMA, AlbuquerqueGM, Amorin RCA, Rodrigues GBA, Silva TS, Jaime PC. Política Nacional de Promoção da Saúde: Descrição da implementação do eixo atividade física e práticas corporais, 2006 a 2014. Rev Bras Ativ Fis Saúde [Internet]. 2014 [cited 2015 Jun 20]; 19(3):286-99. Available from: http:/ / www.periodicos.ufpel.edu.br/ojs2/index.php/ RBAFS/article/viewFile/3427/3280

25. Horta RL, Horta BL, Pinheiro RT, Krindges M. Comportamentos violentos de adolescentes e coabitação parento-filial. Rev Saude Publica [Internet]. 2010 [cited 2014 Dez 10]; 44(6):979-85. Available from: http:/ / www.scielo.br/scielo.php?pid=S0034$89102010000600001 \&$ script $=$ sci_arttext

26. Figueiredo R, Feffermann M, Santos M, Fregnani LMP, Bico RF, Almeida NC. Adoção de orientações visando à prevenção da violência contra escolares: uma ação conjunta entre a saúde e a educação. Bol Inst Saúde [Internet]. 2013[cited 2015 Jul 1]; 14(3):335-43. Available from: http:/ / periodicos.ses.sp.bvs.br/pdf/ bis/v14n3/v14n3a12.pdf

27. Brasil KCTR, Almeida SFC, Amparo DM, Pereira AMR. Adolescência, violência e objetos culturais: uma intervenção entre o educativo e o terapêutico no espaço escolar. Estilos da Clínica [Internet]. 2015 [cited 2016 Mar 2]; 20(2):205-25. Available from: https:// dx.doi.org/10.11606/issn.1981-1624.v20i2p205-225

28. Sá RA, Carneiro SMM, Luz AA. A escola e os sete saberes: reflexões para avanços inovadores no processo educativo. Rev FAEEBA [Internet]. 2013; 22(39):159-69. [cited 2015 Jun 28] Available from: http:/ / www.revistas.uneb.br/index.php/faeeba/article/view/336/286

29. Luna IT, Silva KL, Dias FLA, Freitas MMC, Vieira NFC, Pinheiro PNC. Ações educativas desenvolvidas por enfermeiros brasileiros com adolescentes vulneráveis às DST/aids. Cienc Enferm [Internet]. 2012 [cited Nov 2014]; 18(1):43-55. Available from: http://www.scielo.cl/pdf/cienf/v18n1/art_05.pdf

30. Backes D, Obem MK, Pereira SB, Gomes CA, Backes MTS, Erdmann AL. Incubadora de aprendizagem: ferramenta indutora do empreendedorismo na enfermagem. Rev Bras Enferm [Internet]. 2015 Dec [cited 2016 Mar 2]; 68(6):1103-8. Available from: http://dx.doi.org/10.1590/0034-7167.2015680615i 